\title{
The Effect of Transformational Leadership Style on Employees`Job Satisfaction of Syrian Private Universities
}

\author{
Mohamed Kateb ${ }^{1}$, Prof. K. Ramanathan ${ }^{2}$ \\ Ph.D. (Management), Limkokwing University of Creative Technology, Cyber Jaya, Malaysia ${ }^{1}$ \\ Lecturer, Limkokwing University of Creative Technology, Cyber Jaya, Malaysia ${ }^{2}$
}

\begin{abstract}
Employee job satisfaction is influenced by the internal organizational environment, which includes organizational climate, leadership types and personnel relationships. The leaders in the universities should be aware that transformational leadership styles play an important role in maintaining successful Job satisfaction.. The aim of this study was to examine the effect transformational leadership on job satisfaction of the employees in Syrian private universities. The quantitative method was used in data collection. A two-stage cluster sampling technique was conducted which comprised of 351 faculty members and staff from seven private universities in Syria. A total of three different sets of instruments were used, namely Multifactor Leadership (MLQ), Communicative Competence Scale (CCS) and the Minnesota Satisfaction Questionnaire (MSQ). PLS-SEM technique was used to analyze the relationship between the variables in this study. The study results pointed out that there was a significant relationship between transformational leadership and job satisfaction.
\end{abstract}

Keywords: Transformational leadership, Job satisfaction.

\section{INTRODUCTION}

The Universities around the world always try to improve their education services due to the highly competitive environment. Since leadership plays a critical role in educational organization success (Osseo-Asare et al., 2005) this research is focussed on leadership styles in HEI. Higher education sector has changed together with the changing factors of the world globalization, technological improvements, societal changes and many more. Changes in higher education, according to Oshagbemi (1997) have arisen from "the pressures of demand, the cultural shift in the perception of higher education, financial pressures, structural and managerial diversity, and diversity of university missions or emphases". There are on-going discussions whether HEI should be viewed as business organization, if the same practices should be applied when leading the educational institution.

The freedom of choice and movement gives a student a choice in preferred aspects of HEI - choice according to ranking, reputation, public image, private or public, local or foreign, degree in native language or in foreign language (Alonderiene and Klimaviciene, 2013). What is more, the same factors are also important to the staff and faculty of universities. "HEI's are labour intensive and their budgets are predominantly devoted to personnel, also the effectiveness of higher education institutions is largely dependent on their staff' (Toker, 2011). The competitiveness among universities grows exponentially, performance and quality of teaching, and academic work has to be outstanding.

According to Bryman (2007), effective leader's behaviors in HEI are setting direction, communicating it to the staff, having strategic vision, creating positive organizational climate, being considerate and treating staff fairly, being trustworthy and treating staff with integrity, involving academic staff in key decision making, providing feedback on performance. Academic staff should be able to have the ability to influence the way organization functions, to have enough freedom and autonomy in their position to be able to achieve the goals (Amzat and Idris, 2012).

Working environment has become more intense, and stressful, moreover there is a high pressure to perform, to overcome cultural differences, survive in the globalizing and competitive world. Job satisfaction is commonly understood as a set of emotions, feelings or attitudes toward one's working environment. It is described as a pleasurable feeling which stems from personal perceptions about fulfilments of one's job and values (Noe et al., 2006). Employee job satisfaction is a sense which is desirable in most of the organizations and valued by the staff. It is one of the key indicators of organizational success (Toker, 2011). Lok and Crawford (2004) emphasize that both organizational performance and effectiveness are influenced by the organizational satisfaction and job satisfaction.

A lot of researchers agree that satisfied university staff can contribute to organizational effectiveness, and motivation of staff can trigger better results in student performance, the development of strong organizational culture, better image of the institution and even higher numbers of talented students and faculty members (Siddique et al., 2011; Webb, 2008). 
Although many studies have been focussing on employee satisfaction in business organizations, there has been a growing interest in the research of job satisfaction in HEIs (Toker, 2011). Amzat and Idris (2012) reveal that management's behavior acts as a mediator in the job satisfaction decision making style relationship, and that any behavior of university management has a strong impact on job satisfaction of university staff. The researchers notice that in Europe intrinsic factors such as job rank level, career are the predictors of higher job satisfaction among employees.

Leadership plays a pivotal role in ensuring an effective environment for both the provision of scholarly services and the attainment of strategic goals within any educational institution (Bennett et, al., 2003; Hempsall, 2014; Raz et al., 2012). Critically, leadership plays a more long-term strategic role than management within an educational institution (Raz et al., 2012).

This study tried to find out the relationship between transformational leadership as an independent variable, and employee job satisfaction which would be considered as a dependent variable.

\section{LITERATURE REVIEW}

\section{Transformational Leadership Style}

Transformational leadership is the practice of leadership behaviors that empower followers to create vision, to promote change, and to achieve a meaningful and satisfying work environment (Bass, 1985).

Also defined as "a process in which the leaders take actions to try to increase their associates' awareness of what is right and important, to raise their associates' motivational maturity and to move their associates to go beyond the associates' own self-interests for the good of the group, the organization, or society. Such leaders provide their associates with a sense of purpose that goes beyond a simple exchange of rewards for effort provided" (Bass and Avolio, 1997).

Yukl (2002) defined transformational leadership as "a process of bringing about crucial changes in the members' attitudes and assumptions and obtaining their commitment for the purpose of fulfilling the organization's mission and objectives". Bass (1985) further extended the concept of transformational leadership and presented a more elaborate expansion of the construct. Bass (1985) and Waldman et al. (1988) also added that transformational leaders tend to enhance and raise the overall awareness of their employees so that they can contribute towards achieving the different outcomes, goals and vision required by an organization.

Avolio and Bass (1999) attempt to identify certain characteristics for transformational leaders, arguing that leaders typically look for new approaches to accomplish objectives by seeking new opportunities in the face of risks (Michaelis, et al., 2010). The leader also favours effectiveness over efficiency. Additionally, transformational leaders prefer innovative thinking and, accordingly, they are unlikely to maintain the status quo in their organizations (Panagopoulos and Dimitriadis, 2009). Furthermore, transformational leaders tend to create, shape and form from the external circumstances, rather than just acting in response to them (Yiing and Ahmad, 2009). Schyns, et al., (2009) stress that one of the main attributes of the transforming leader is that they recognize and exploit the existing needs or demands of their potential followers. According to this view, the transforming leader continuously looks for potential motives in their followers, seeks to satisfy their higher needs and fully engages with their followers. In support of this view, Politis (2006) argues that transformational leaders should assess their followers' potentiality and ability to perform certain tasks.

According to Bass (1985), leaders transform and motivate followers by, creating a new vision and emphasizing the importance of particular task outcomes, encouraging followers to move beyond their own interests for the sake of the organization, and stimulating the followers 'higher order needs. Transformational leaders influence subordinates by motivating and inspiring them to achieve organizational goals (Bass and Avolio, 1994).

Bass (1985) declared that transformational leaders inspire their followers to go above and beyond their own self interests for the sake of the organization as a whole. As a result, these leaders are able to bring a deeper insight and appreciation of input received from each member. Bass (1985) further argued that transformational leaders encourage followers to think critically and look for new approaches to do their jobs. Moreover; according to Newman and Grigg (2008) a transformational leader expects followers to provide divergent thinking and not simply to agree. These challenges given to followers motivate them to become more involved in their tasks. This, in turn, leads to greater satisfaction with their work and commitment to their Organization.

\section{Job satisfaction}

Job satisfaction has been defined in many ways but usually it can be considered as attitude (Weiss and Cropanzano, 1996), emotional feelings towards the job itself either the feeling of positive or negative because of one job experiences (Odom, Boxx, and Dunn, 1990), pleasurable emotional state resulting from appraisal of one's job (Brief, 1998), and 
positive orientation towards the job. Happock (as cited in Aziri, 2011), defines job satisfaction in combination of element psychological, physiological and environmental and this approach focuses on the internal feeling of employees. Job satisfaction is an important element of success in an organization. Job satisfaction is an important research topic in industrial and organisational psychology (Amburgey ,2005).

Warr (2007) regards job satisfaction as one important dimension of an individual's happiness at work. Plenty of attention has been given to Job satisfaction in recent years, resulting in the construct being extensively researched over the past years. Some scholars believe that job satisfaction is about people and their jobs, and when organizations promote job satisfaction, they will gain the benefits of increased employee commitment, performance, and retention as well as reduced absenteeism and attrition (Helland and Winston, 2005). Syptak, Marsland, and Ulmer (1999) proposed that satisfied employees tend to be more productive, creative and committed to their employers.

According to Dawson (2005), employee satisfaction is connected with employee behavior which is positive in nature. It is true that satisfied workers generate clients who are satisfied and undeniably loyal. Job satisfaction/dissatisfaction is applicable to different kinds of employees, regardless of the type of work they do. Attitudes of employees do have an impact when positivity is seen towards their jobs which means they are satisfied with their job. A lot of researchers agree that satisfied university staff can contribute to organizational effectiveness, and motivation of staff can trigger better results in student performance, the development of strong organizational culture, better image of the institution and even higher numbers of talented students and faculty members (Siddique et al., 2011; Webb, 2008).

Toker (2011) finds the satisfaction with compensation, supervision, salary, fringe benefits are evaluated lowest by the academics. Satisfaction with social status, social service and ability utilization is evaluated highest. Toker's (2011) also noticed that there is a statistically significant relationship between job satisfaction and academic titles, age and the years spent in the HEI. Higher rank, elderly staff and longer working staff are more satisfied with their job. There is no significant difference in respondent's marital status and gender. On the contrary, in Sukirno and Siengthai (2011) study demographic variables like age, gender and experience have no significant effect on performance, while academic rank has positive effect on performance and job satisfaction of faculty in HEI.

\section{THE RELATIONSHIP BETWEEN THE VARIABLES AND HYPOTHESIS DEVELOPMENT}

The result of most previous studies has proved the relationship between transformational leadership and job satisfaction.

Saleem (2015) shows transformational leadership has positive association with job satisfaction through their inspiring and motivating behavior. Leadership has also received a huge amount of attention, especially in higher education institutions (Alonderiene and Majauskaite, 2016).

Employee job satisfaction is considered to be one of the most widely studied phenomena in organisational and leadership studies, and hence multiple attempts have been made by researchers to evaluate and analyse it with reference to different aspects of organisations such as leadership, work environment, employee performance, organisational energy and more (Sun et al., 2016; Reid and Adler 2008; Buckman, 2015; Safi et al., 2016). Job satisfaction, as described by Hasenfeld (2009), refers to the overall level of contentment that employees have with respect to their job and their supervisors.

It is also argued that in order to enhance employees' job satisfaction, it is important for leaders and managers to establish a good relationship with their subordinates, which is a core behaviour of a transformational leader (Braun et al., 2013; Yildiz and Simsek, 2016; Top, Akdere and Tarcan, 2015). On the other hand, Grosso (2008) argues that adopting and utilising transformational behaviours in a higher education institution setting will create a harmonic and efficient atmosphere sufficient enough to achieve not only academic and administrative staff goals, but also the organisation's aims, mission and vision.

Brown and Moshavi (2002) distributed the MLQ to 70 department chairs at various land-grant universities and determined that individual characteristics of transformational leadership were found posittively linked to faculty satisfaction. Other studies reported that transformational leadership is related with teacher outcomes. Fernandes and Awamleh, (2004) in their study, confirmed that Transformational leadership style of mangers is related to job satisfaction and will boost employees' job satisfaction. Barnett et al. (2005) found a strong correlation between transformational leadership and teacher job satisfaction in secondary education. The very fact that transformational leaders are connected with their subordinates will ensure that the employees are more motivated and satisfied. Furthermore, the morale of the employees gets a boost. Yukl (2010) mentioned that employees are more satisfied as opposed to being dissatisfied when transformational styles of leadership are being displayed.

He also suggested that transformational leaders are leaders who are visionary and authentic, and who use transforming methods of leadership to change and improve organization. According to the transformational theory "the relationship between transformational leadership and personal outcomes such as job satisfaction is well established" (Bass, 1998). It was assumed that in universities where leaders use transformational behaviors, job satisfaction will be higher. Based on the studies findings and explanation the first hypothesis was proposed as the following: 


\title{
International Advanced Research Journal in Science, Engineering and Technology
}

\author{
Vol. 6, Issue 8, August 2019
}

H1: There is a significant relationship between transformational leadership and employees 'job satisfaction.

From the description above, we can describe the research model as follows:

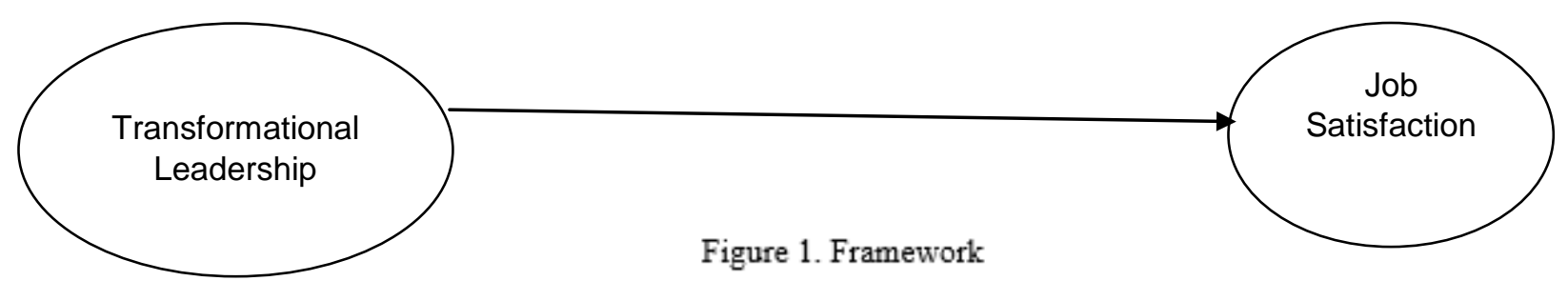

\section{RESEARCH METHODOLOGY}

Research Design: Quantitative research data are usually collected through questionnaires. Questionnaires are considered the single most popular data collection tools in any research involving human subjects (Pickard, 2007). Questionnaires should used to collect data because this method was both time consuming and cost effective (Dillman, 1991). As a result, questionnaires were used in this study to collect data. This study was cross-sectional as opposed to being longitudinal in which data was collected more than once throughout the study period (Sekaran, 2003). The data was collected once the final questionnaires were available after taking into account the modifications that had to be incorporated for the final study.

Population: The population for this research is all the employees who are working in the private universities of Syria excluding employees with leading role (leaders, supervisors and deans). The researcher excluded leaders, supervisors and deans because this study was concerned with an investigation of their leadership style, so the respondents were only faculty members and staff. The employee's rating of their leaders' leadership styles would be more valid than the leaders`self rating. This claim was supported by many studies (Kelley et al., 2005; Johnson et al., 2007).

Sampling Design: The private universities in Syria include twenty-two university distributed in different locations in Syria. Seven private universities were selected from 22 private universities in total by using two-stage cluster sampling technique. Based on the recent (2018) statistics of employment in universities of Syria, the total population of employees in all levels and working in the private universities is 5098. This study follows Krejcie and Morgan (1970) for determining sample size; the total targeted population size was 4078 possible participants. According to Krejcie and Morgan (1970), for a population size of 4078, the sample size should be around 351 participants.

\section{RESULTS AND DISCUSSION}

The results of the study show transformational leadership Style affects job satisfaction with R2 $=0.454$, path coefficient $\beta=0.317$, and Q2 $=0.299$. In this study, there was 1 hypothesis tested and based on the results of test. The results showed that $\mathrm{H} 1$ hypothesis are supported by the data.

Table 1. The Hypothesis Test of Research Model

\begin{tabular}{|c|l|c|c|}
\hline Hypothesis & \multicolumn{1}{|c|}{ Hypothesis Statement } & T-Value & Result \\
\hline H1 & $\begin{array}{l}\text { There is a significant relationship between transformational leadership and } \\
\text { employees jjob satisfaction. }\end{array}$ & 8.02 & Supported \\
\hline
\end{tabular}

The result of testing the hypothesis found that:

Hypothesis 1: The H1 hypothesis was supported and accepted. The H1 hypothesis predicted that transformational leadership style will positively influence employee job satisfaction in private Syrian universities.

\section{CONCLUSION}

The study results figured out that transformational leadership style had a significant relationship with job satisfaction. in the private universities in Syria. Employees are one of the most important assets for an organization. Their role is vital to the organization's success. In higher educational context for example, a faculty member plays an important role in providing quality teaching to the students, enhancing their skills and doing research. Thus, it is important for the organization to ensure that they have high job satisfaction. Also, other staff should have high job satisfaction while they provide services and complete their job tasks. 


\title{
International Advanced Research Journal in Science, Engineering and Technology
}

\author{
Vol. 6, Issue 8, August 2019
}

In conclusion, this study was successful in making a significant contribution to the existing literature by further exploring the impact of transformational leadership style on job satisfaction by empirical analysis. It is to be noted that using transformational leadership style should lead to increased job satisfaction among employees. This in turn could result in enhanced performance among employees, commitment, productivity, working climate and encourage employees to stay in the university and contribute to greater organizational effectiveness.

\section{REFERENCES}

[1]. Alonderiene, R. and Klimavičiene, A., 2013. Insights into Lithuanian students' choice of university and study program in management and economics. Management: journal of contemporary management issues, 18(1), pp.1-22.

[2]. Alonderiene, R. And Majauskaite, M., 2016. Leadership style and job satisfaction in higher education institutions. International Journal of Educational Management, 30(1), pp.140-164.

[3]. Amburgey, W.O.D., 2005. An analysis of the relationship between job satisfaction, organizational culture, and perceived leadership characteristics.

[4]. Avolio, B. J., Waldman, D. A. and Einstein, W. O., 1988. Transformational Leadership in a Management Game Simulation. Group \& Organization Studies, 13(1): 59-80.

[5]. Avolio, B.J., Bass, B.M. and Jung, D.I., 1999. Re-examining the components of transformational and transactional leadership using the Multifactor Leadership. Journal of occupational and organizational psychology, 72(4), pp.441-462.

[6]. Aziri, B., 2011. Job satisfaction: A literature review. Management research and practice, 3(4), 77-86.

[7]. Barnett, A.M., Marsh, H.W. and Craven, R., 2005. What type of school leadership satisfies teachers? A mixed method approach to teachers' perceptions of satisfaction. In Australian Association for Research in Education 2005 conference papers.

[8]. Bass, B. M. and Avolio, B. J., 1994. Improving organizational effectiveness through transformational leadership. SAGE Publications, Incorporated.

[9]. Bass, B. M. and Avolio, B. J., 1997. Full range leadership development: Manual for the multifactor leadership questionnaire. Palo Alto, CA: Mindgarden.

[10]. Bass, B. M., 1998. Transformational leadership: Industrial, military, and educational impact.Mahwah, NJ: Lawrence Erlbaum Associates.

[11]. Bass, B.M., 1985. Leadership and performance beyond expectations. Collier Macmillan.

[12]. Braun, S., Peus, C., Weisweiler, S. and Frey, D., 2013. Transformational leadership, job satisfaction, and team performance: A multilevel mediation model of trust. The Leadership Quarterly.

[13]. Brief, A. P., 1998. Attitudes in and around organizations (Vol. 9). London : Sage Publications Inc.

[14]. Brown, F. W. and Moshavi, D., 2002. Faculty reactions to transformational and contingent reward leadership by department chairs. Journal of Leadership Studies, 8(3), 79-93.

[15]. Bryman, A., 2007. Effective Leadership in Higher Education Summary of findings. London: Leadership Foundation for Higher Education.

[16]. Buckman, B., Crawford, E., LePine, J. and Zhang, Y., 2015. A meta-analytic investigation of job engagement's role in the transformational leadership-job satisfaction-job performance relationship. In Annual Meeting of the Southern Management Association, SMA 2015.

[17]. Dawson, B., 2005. Motivating leaders to better results. Journal of Rubber and Plastics, 37, 11-15.

[18]. Dillman, D. A., 1991. The design and administration of mail surveys. Annual Review of Sociology, 17, 225-249.

[19]. Fernandes, C. and Awamleh, R., 2004. The impact of transformational and transactional leadership styles on employee's satisfaction and performance: an empirical test in a multicultural environment, International Business and Economics Research, 3(8), 65-76.

[20]. Gardenswartz, L., Rowe, A., Digh, P. and Bennett, B., 2003. The global diversity desk reference: managing an international workforce. NJ: Wiley Publishers.

[21]. Grosso, F.A., 2008. Motivating faculty through transformational leadership: A study of the relationship between presidential leadership behaviors and faculty behaviors. ProQuest.

[22]. Hasenfeld, Y., 2009. Human services as complex organizations. Sage Publications.

[23]. Helland, M.R. and Winston, B.E., 2005. Towards a deeper understanding of hope and leadership. Journal of Leadership \& Organizational Studies, 12(2), pp.42-54.

[24]. Hempsall, K., 2014. Developing leadership in higher education: Perspectives from the USA, the UK and Australia. Journal of Higher Education Policy and Management, 36(4), pp.383-394.

[25]. Huey Yiing, L. and Zaman Bin Ahmad, K., 2009. The moderating effects of organizational culture on the relationships between leadership behaviour and organizational commitment and between organizational commitment and job satisfaction and performance. Leadership \& Organization Development Journal, 30(1), pp.53-86.

[26]. Hussein Amzat, I. and Abdul Rahman Idris, D., 2012. Structural equation models of management and decision-making styles with job satisfaction of academic staff in Malaysian Research University. International Journal of Educational Management, 26(7), pp.616-645.

[27]. Johnson, B., Stevens, J.J. and Zwoch, K., 2007. Teachers' perception of school climate: A validity study of scores from the revised school level environment questionnaire. Educational and psychological measurement, 67(5), 833-844.

[28]. Kelley, R., Thornton, B. and Daugherty, R., 2005. Relationships between measures of leadership and school climate. Education Indianapolis Then Chula Vista, 126(1), 17-28.

[29]. Klein, H.J., Noe, R.A. and Wang, C., 2006. Motivation to learn and course outcomes: The impact of delivery mode, learning goal orientation, and perceived barriers and enablers. Personnel psychology, 59(3), pp.665-702.

[30]. Krejcie, R.V. and Morgan, D.W., 1970. Determining sample size for research activities. Educational and Psychological Measurement, 11, 3335 .

[31]. Lok, P. and Crawford, J., 2004. "The effect of organizational culture and leadership style on job satisfaction and organizational commitment: a crossnational comparison", Journal of Management Development, 23(4), 321-338.

[32]. Michaelis, B., Stegmaier, R. and Sonntag, K., 2010. Shedding light on followers' innovation implementation behavior: The role of transformational leadership, commitment to change, and climate for initiative. Journal of Managerial Psychology, 25(4), pp.408-429.

[33]. Newman, J. and Grigg, D., 2008. Leaders who affect change are highly regarded. Telegraph-Journal, E.7. 


\title{
International Advanced Research Journal in Science, Engineering and Technology
}

\author{
Vol. 6, Issue 8, August 2019
}

[34]. Odom, R. Y., Boxx, W. R. and Dunn, M. G., 1990. Organizational cultures, commitment, satisfaction, and cohesion. Public Productivity \&amp; Management Review, 157-169.

[35]. Oshagbemi, T., 1997. Job satisfaction and dissatisfaction in higher education. Education Training, 39(9), pp.354-359.

[36]. Osseo-Asare, A.E., Longbottom, D. and Murphy, W.D., 2005. Leadership best practices for sustaining quality in UK higher education from the perspective of the EFQM Excellence Model. Quality Assurance in Education, 13(2), pp.148-170.

[37]. Panagopoulos, N. and Dimitriadis, S., 2009. Transformational leadership as a mediator of the relationship between behavior-based control and salespeople's key outcomes: An initial investigation. European Journal of Marketing, 43(7/8), pp.1008-1031.

[38]. Pickard, J., 2007. Research methods in information. London: Facet Publishing, 183- 199.

[39]. Politis, J.D., 2006. Self-leadership behavioural-focused strategies and team performance: The mediating influence of job satisfaction. Leadership \& Organization Development Journal, 27(3), pp.203-216.

[40]. Raz, S., Hojati, Z., Najafian, M., and Namdari, R., 2012. A survey on the relation between leadership's characteristics and organizational health in universities (case study Islamic Azad Universities of district 6). Australian Journal of Basic and Applied Sciences, 6(13), 221-227.

[41]. Reid, J. and Adler, R.W., 2008. The Effects of Leadership Styles and Budget Participation On Job Satisfaction And Job Performance. AsiaPacific Management Accounting Journal, 3(1).

[42]. Safi, M.H., Mohamadi, F., Amouzadeh, I. And Arshi, S., 2016. The Relationship between Manager'Leadership Style with Job Satisfaction and Burnout in Staff of Shomal Health Center of Tehran. Community Health, 2(2), pp.88-97.

[43]. Saleem,H., 2015. The impact of leadership styles on job satisfaction and mediating role of perceived organizational politicism , Social and Behavioral Sciences 172, $563-569$

[44]. Schyns, B., van Veldhoven, M. and Wood, S., 2009. Organizational climate, relative psychological climate and job satisfaction: The example of supportive leadership climate. Leadership \& Organization Development Journal, 30(7), pp.649-663.

[45]. Sekaran, U., 2003. Research methods for business (4th ed.). NJ: John Wiley \& Sons.

[46]. Siddique, A., Aslam, H.D., Khan, M. and Fatima, U., 2011. Impact of Academic Leadership On Faculty's Motivation And Organizational effectiveness In Higher Education System. International Journal of Academic Research, 3(3).

[47]. Simsek, A. and Yildiz, M., 2016. Durability, deadline, and election effects in bargaining (No. w22284). National Bureau of Economic Research.

[48]. Sukirno, D.S. and Siengthai, S., 2011. Does participative decision making affect lecturer performance in higher education?. International Journal of Educational Management, 25(5), pp.494-508.

[49]. Sun, Y., Gergen, E., Avila, M. and Green, M., 2016. Leadership and Job Satisfaction: Implications for Leaders of Accountants. American Journal of Industrial and Business Management, 6(03), p.268.

[50]. Syptak, J.M., Marsland, D.W. and Ulmer, D., 1999. Job satisfaction: Putting theory into practice. Family practice management, 6(9), p.26.

[51]. Toker, B., 2011. Job satisfaction of academic staff: an empirical study on Turkey. Quality Assurance in Education, 19(2), pp.156-169.

[52]. Top, M., Akdere, M. and Tarcan, M., 2015. Examining transformational leadership, job satisfaction, organizational commitment and organizational trust in Turkish hospitals: public servants versus private sector employees. The International Journal of Human Resource Management, 26(9), pp.1259-1282.

[53]. Warr, P., 2007. Work, happiness and unhappiness. Mahwah: Lawrence Erlbaum.

[54]. Webb, K.S., 2008. Creating satisfied employees in Christian higher education: Research on leadership competencies. Christian Higher Education, 8(1), pp.18-31.

[55]. Weiss, H. M. and Cropanzano, R., 1996. Affective events theory: A theoretical discussion of the structure, causes and consequences of affective experiences at work. Research in Organizational Behavior, 8, 1-74

[56]. Yukl, G., 2002. Leadership in organizations (5th ed). Englewood Cliffs NJ: Prentice Hall

[57]. Yukl, G., 2010. Leadership in organizations (7th ed.). Upper Saddle River, NJ: Prentice Hall. 